\title{
Subverting Scriptures: Critical Reflections on the Use of the Bible, edited by Beth Hawkins Benedix
}

New York: Palgrave Macmillan, 2009 | $\mathrm{x}+245$ pages | ISBN: 978-0-230-61069-9 (hardback) \$85.00

In this book, Beth Hawkins Benedix has brought together a diverse collection of essays which examine ways in which biblical texts are appropriated, transformed and "subverted" in contemporary cultures,

SUBVERTING

SCRIPTURES

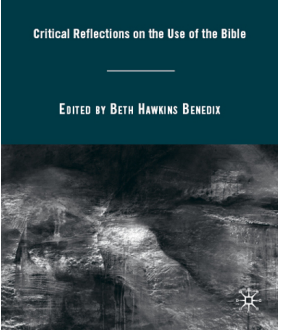
most prominently, and unsurprisingly given its provenance, the modern United States. As a southern hemisphere reader, I was struck by how unselfconsciously this collection proclaims its U.S. provenance. The opening sentence cites Jacques Berlinerblau naively declaring "The Bible is back!" (from his book on the use of biblical texts in U.S. presidential politics) —as if it ever really went away-to launch into a short survey of Obama's use of biblical references in his campaign discourse. I will have more to say towards the end of my review about this U.S., and might I say U.S. Protestant, provenance and how it has, ironically, subverted these scholarly approaches seeking to subvert its biblical frame.

Beth Hawkins Benedix is associate professor of Religious Studies and Literature at De Pauw University and her acknowledgements include her students from her course on biblical literature from which the "spark of inspiration for this collection came" (ix). The anthology consists of eleven chapters divided into four sections, together with an introduction. The book also includes a short subject index (which includes biblical texts) but no single bibliography. Instead, bibliographies are provided at the end of each essay together with references in endnotes. I prefer footnotes and in-text refer- 
encing as much less disruptive to reading as opposed to endnotes, especially when, as in this case, placed at the end of each chapter. Nevertheless, I found myself thoroughly engaged in the material of each essay (effectively ignoring most of the endnotes).

Taken as a whole the essays explore a diverse range of literary and religious writers and the ways they re-write and deploy the biblical literature in their work. As Benedix points out in her Introduction, the essays' authors ask "what are these writers doing $[s i c]$ when they point to the Bible in their work" and what "is the relationship ... between biblical text and political message for these writers" (2). She continues that there are two main tendencies amongst these writers, one which regards the biblical texts more positively as a resource for critique, "guidance and instruction" while the other "tends to look at the Bible with suspicion and distrust, seeing in it the seeds for widespread injustice" (ibid.). Both tendencies share the perspective that the world is damaged and in need of repair. How scripture is regarded then is determined by whether scripture is deployed as a tool for subversion or as an object, itself, of subversion. Invariably, the one will involve the other, especially in the latter instance where subverting the authoritative scripture paradoxically both unleashes subversive dimensions within scripture and reinscribes scripture's authoritative status within society and culture.

The first section, "Setting the Stage: What is Subversive Scripture?," consists of two essays addressing precisely these questions of rewriting scripture and scriptural subversions (while at the same time underscoring the U.S. provenance of the anthology). Jay Twomey's study, "A Funny Thing Happened on the Road to Damascus: Piety and Subversion in Johnny Cash's Man in White," explores the way even pious rewriting of scripture will be subversive despite the author's intent. This novel of the life of St Paul recasts Paul's heavenly ascents within the universe as understood by the science of Cash's twentieth-century world. As Twomey describes it, Cash gives a profoundly modern cosmic dimension to Paul's visions. Indeed, such re-telling, re-appropriation of scriptures is essential for them to maintain their standing in the face of cultural change. Cash's treatment is congruent with the dynamics of these scriptures themselves but the paradox is that he subverts the worldview of the religious system, conservative evangelical Protestantism, of which he is both a part and striving to advance. Cash is quintessentially a product of American culture and so too is creation science, born from that same conservative evangelical Protestant matrix that Cash so piously under- 
mined. Creation science combines biblical literalism with the authority of modern science to argue the inerrancy, and hence the literal normativity, of the text. In "Refuse, Realism, Retelling: Literal and Literary Reconstructions of Noah's Ark," Lesleigh Cushing Stahlberg explores such literal rewritings of the Flood stories in creation science discourse and compares and contrasts them with more literary re-imaginings of Noah and his Ark. Both groups share a concern with shit. With so many animals on board how did Noah and his family deal with all that shit? Creationists develop elaborate techniques of scatological engineering to buttress the literal veracity of the story. The four literary writers (three of whom are from outside the U.S.) examined by Stahlberg use scatology to (playfully) engage with the story to deconstruct and critique it.

The two essays of the second section, "Between Speech and Silence," address both the challenge to scripture posed by the Holocaust and the way scripture has been deployed in response to that catastrophe. John K. Roth, "Face to Face: Biblical Traces in the Philosophy of Elie Wiesel," engages with the biblical dynamics haunting the work of Elie Wiesel. Wiesel uses scripture not so much to challenge the Holocaust but to protest the inadequacy of scripture to account for it. Does this inadequacy disclose a failure within the divine itself and how does one respond to it, be one Jewish (Wiesel) or Christian (Roth)? But Roth goes too far in claiming not just Wiesel, but scripture and Judaism and even "God" as "Protestant" (57), betraying again the U.S. (imperialist) provenance of the anthology. More satisfying was John Felstiner's study of the poetry of Paul Celan, "Mother Tongue, Holy Tongue: On Translating and not Translating Paul Celan." I found Felstiner's discussion of Celan's (post-Holocaust) German-language poetry and his deployment of Hebrew therein (and the issues of translation it raises), enriching, provocative and haunting.

As its title, "Revolution, Rebellion, Liberation," suggests, the third section addresses more overtly political concerns. Qiuyi Tan's essay, "Textual Hijacks: Between the Book of Isaiah and The Handmaid's Tale," juxtaposes Margaret Atwood's novel of a rigorous biblically-based theocracy in the (post-) United States with the book of Isaiah, bringing together dystopia and utopia to explore their intertextual connections. Against a nightmare world of gender and political oppression, Atwood offers "the anti-fundamentalist act of interpretation" that celebrates the text's "unsettling indeterminacy" and heartening "capacity to generate a multiplicity of meanings" (I05). The issues of utopia, community, identity and liberation are addressed in Anna Hart- 
nell's discussion of the use of Exodus themes in Toni Morrison's novel Paradise ("Exodus and Redemption in Toni Morrison's Paradise: A Magical Encounter with the Bible"). Paradise is set in the fictional African-American town of Ruby founded following the Exoduster movement of African Americans from the south in I 879. Ruby's founders are rejected by both black and white communities because of their exceptionally dark complexions but ironically Ruby comes to "embody a disturbing mirror image of white supremacy" and the novel "charts an Exodus narrative that finds itself on a circuitous pathway back to Egypt” (I I I). Ellin Jimmerson's essay, “In The Beginning-Big Bang': The Issue of Violence in Ernesto Cardenal's Cosmic Canticle, "takes us outside of U.S. concerns to explore the poetry of Ernesto Cardenal, Roman Catholic priest and culture minister in the Sandinista government of Nicaragua. Cardenal's massive poetic work, Cosmic Canticle, uses the opening of Genesis to blur the line between violence and non-violence to instead develop "a distinction between two fundamentally different kinds of violence" ( 128 ). One is "ordained by capitalism ... and deals in death and division" while the other is "God-ordained, procreative, evolutionary and revolutionary and will culminate in holistic communion" (I 44).

The four essays in the final section, "Exposing the Will to Power," explore the claim to power both within and built upon biblical texts, not least through the canonical process. In "Babel Revisited: Kafka and Pinter Critique the Covenant," Beth Hawkins Benedix imagines "Kafka alongside Pinter, privy to the same political landscape and equally disturbed by the toxicity of the religious rhetoric" (I 52). Both Kafka and Pinter take seriously the power inherent in stories which can be considerably greater than if their authority were based in an external reality somewhere and not imagination. I really enjoyed this essay and the insights (revelations?) Benedix drew from the juxtaposition of these two writers with each other and with the biblical narratives. The interplay of Exodus and Egypt resumes with Ranen OmerSherman ("Masters, Slaves, and the Implacable Deity of the Wilderness in Simone Zelitch's Moses in Sinai") in his reading of Simone Zelitch's novel, Moses in Sinai, her "Last Temptation of Christ for Jews" (178). In her novel, Zelitch utilizes the interplay of "obedience and authority as embodied by Moses' austere faith and Korah's humanistic rebellion" ( 778 , cf. Numbers I6) to address the contradictions within humanitarian political movements and the building of just societies "without the 'slaves' (oppressed) becoming the masters or oppressors" (I78). Omer-Sherman observes that these issues have been thrown into stark relief for Jews everywhere, with the cre- 
ation of the Zionist state of Israel (itself a kind of Ruby writ large). Being reconciled to divine absence is a recurring theme in all the Jewish contributions to Subverting Scriptures. Quite the opposite is the case in W. David Hall's study of the Rapture culture of U.S.-based Protestantism and the execrable novels of the Left Behind series ("The Modern Day Followers of the Lamb: The Rhetoric of Suffering and the Politics of Identity in the Left Behind series"). These novels help shape a communal identity based on both victimhood and schadenfreude through a literary vision of the "imminent, physical, and violent wrath of God" (2I I) striking the perceived enemies of dispensationalist Christians, the others outside their world/faithview. I have only read bits of these novels myself but have studied this (to me, bizarre) form of Christianity for some time. While I agree with Hall that "demonizing dispensationalist Christians as dangerous fanatics" (2 I4) is a dangerous path to tread, that they "are much more like the normal run of American" and other "citizens than some might like to admit," I was surprised by how kind Hall was in his reading of the Left Behind world. His was in striking contrast to that of Fred Clark, a progressive, nondispensationalist evangelical Christian, who has run a weekly series on his blog (http://slacktivist.typepad.com/slacktivist/left_behind/) for some eight years now in which he progressively reads and deconstructs a portion of the Left Behind novels and films. I am also concerned that Hall seems to have given up on any role for biblical scholars in countering the Left Behind culture. The power and claim of these books relies on a biblical (and theological) illiteracy that scholarship should seek to redress.

Ironically, biblical illiteracy is thrown into stark relief in the final essay, Shaul Magid's "Subversion as Return: Scripture, Dissent, and Renewal in Contemporary Judaism." Magid wants to examine the way the Bible and "its tentacles, now in their third millennium of maturation, both contribute to and impede our ability to rethink Judaism in the next century" (2 I 7 ). Crucial for Magid is the question of canon (and it was gratifying, at first, to see Magid referring to "Bibles" and not just Bible); he revisits the Hebrew canon "as a text born of dissent and subversion" (2 I 8), a consciously rabbinic project. Crucial for his argument is to compare the plurality of canons, of canonisation processes in Judaism and Christianity after the destruction of the Temple. He takes as his point of contrast the endpoint of the Hebrew Bible at 2 Chronicles 36:23 to show that "Judaism is a religion in waiting" (220). He then turns to Christianity and the canonization of the Old Testament, writing: "The Christian canonizers had something different 
in mind when they concluded the Hebrew Bible, their 'Old Testament' with the prophetic words of the prophet Malachi” (220). This statement is wrong on two counts. Firstly, the ancient Christian canonisers took as their Old Testament the Greek Bible (LXx) not the Hebrew Bible. Secondly, the ancient Christian canonisers did not end their Old Testament with Malachi. One of the oldest Christian Bibles, Codex Vaticanus, ends its Old Testament with Daniel (which is also the last book of the Orthodox Bible). The oldest Christian Bible, Codex Sinaiticus, places Malachi as part of the Twelve at the start of its prophetic corpus, which presumably ended with Daniel (both Daniel and Ezekiel are missing) but then follows its prophets with the four books of Maccabees. Codex Alexandrinus ends its Old Testament with Sirach, the prophets and four books of Maccabees forming the centre of its Old Testament instead. Augustine understood the order of the prophets as The Twelve, Isaiah, Jeremiah, Daniel and Ezekiel (De doctrina christiana 2.I3). Malachi's position concluding (only) one contemporary Old Testament canon is due to the history of the shaping of the Latin Bible in the medieval West and then the Reformation. The Reformers took the Jewish Hebrew Bible as their Old Testament and banished the other texts of the Latin Old Testament (which ends with I-2 Maccabees and remains in the Roman Catholic canon today) to the Apocrypha, which in the nineteenth century disappeared from printed Protestant Bibles due to evangelical pressure. Malachi's canonical position then is almost accidental and is a feature of Evangelical Protestant Bibles only. I strongly agree with Magid on the need to recognize canonical plurality as a means of renewing and rethinking biblical religions today (and I would remind him that the Talmud Bavli records an alternative Hebrew Bible in the order of its prophets and the inclusion of Sirach, while the Ethiopian Jews had a Bible of their own, different to the rabbinic canon). However, Magid has fallen for a cultural/canonical sleight of hand. He falsely assumes that there has only ever been one Christian canon and that the canon of U.S. evangelical Protestantism is it. It is not, of course; it is but (a most recent) one of several Christian canons extant and over time. But it so strongly shapes U.S. culture to the point that it can even subvert the historical perspectives of scholars from other faiths. Ironically, while wanting to address broader Jewish concerns, Magid's essay most clearly (and unconsciously) of all reveals the American provenance of this anthology.

If I sound too critical let me say that there is much in this anthology to delight a wide readership, not least biblical scholars and other academics. I would use it in a range of courses in biblical studies, especially those examin- 
ing relationships of scripture with literature and culture. It can also be used more broadly in general literary and cultural studies, too (not least because of Felstiner's and Benedix's essays). Because it has a large number of Jewish contributors, it is likewise a valuable resource for Jewish Studies courses. Finally, because its U.S. provenance is both unconscious and yet disclosed, this book should prove a valuable resource for studies of U.S. literature, culture and politics.

Michael Carden

Brisbane 